\title{
An Examination of Agreement Between the Parties on Preceding the Time of Transfer the Ownership from the Moment of Signing the Contract
}

\author{
MASKONI Ali Arefi ${ }^{34}$, POOR CHANGIZ Mohammad Amin ${ }^{35}$
}

\begin{abstract}
Based on their consequences, contracts are divided into different types, one of them being "possessory contract". The basic consequence of these kinds of contracts is actually alienating possession from one party to another. Since alienation - as the most perfect example of objective rights, which give the owner the authority to possess all the possession - can be the source of various rights and obligations for the transferor and the grantee, the way and time of transfer, including sale, has always been of interest to lawyers. Following the jurisprudence, Iranian law has accepted alienation as a principle in the concept of possessory contracts from the moment of signing the contract (which can be different in consented, objective or ceremonial contracts regarding the cause). But the effect of the interactive parties' will and agreement in advancing or postponing this time has rather been ignored.

This paper examines validity in the condition of advancing alienation from the time of signing the contract in order to resolve disagreements and reach a proper solution in this regard.

This has been done through searching through library resources including juridical and law books and related laws in descriptive analysis method and gave us the results that, firstly, at the time of signing the contract, alienation requires assigning possessory contracts and not the contract itself.
\end{abstract}

Keywords: possessory contracts, Transfer the ownership, The Condition of Advancing Alienation, Iran's Law

UDK: 347.47

005.591.43

COBISS.SR-ID 253517324

\section{Introduction}

Iranian civil code does not mention classifying contracts into promissory and possessory contracts in the chapter regarding types of contracts and commitments (articles 184-189). But in article 825 on wills according to jurisprudence, it divides wills into two types of promissory and Accrual. It also mentions or explains the effects of certain contracts while defining them; including contract of sale (article 338), lease (article 466), donation (article 795) and debt (article 648) in possessory contracts, and contract of reward, (article 561), guarantee (article 684), bailment (article 734) and assignment (article 724) in promissory contracts. But apparently, the civil law has taken the promissory and Accrual concepts for granted, or put the

34 Law at the Faculty of Law and Theology, Shahid Bahonar University of Kerman, Iran, aliarefi4762@yahoo.com

${ }^{35}$ Ferdowsi University, Mashhad, Iran, poorchangiz94@mail.um.ac.ir 
jurists in charge of explaining them, so it gives no definition of these two words in the articles above. Iranian law literature states the following on promissory and possessory contracts: "a possessory contract is a contract through which alienation is done; i.e. the object of transaction is taken out of one party's possession, which is the transferor, and is brought into the other party's possession, which is the grantee. A promissory contract is one that creates religious right and obligation for a party regarding the other party; or for each of the parties regarding each other" (Emami; 1366, p. 67). Regarding the time of alienation in possessory contracts, and without specifying any conditions, the first clause in article 362 of Iranian determines, through a general law, that the possession of the object of sale is transferred to the purchaser "upon the sale". It seems as if this article is an implication of the famous opinion of Shia Jurisprudents who believe the alienation of the object of sale to be instant and simultaneous to signing the contract. The Jurisprudents explain this famous theory on their stands through this sentence: "The sold possession is taken into the purchaser's possessions as soon as the contract is signed".

Using this theory through this sentence is so common that it can be known as a rule (Jafari Langeroodi; 1381, p. 226), and in this paper, we also use it as the rule of instant alienation.

The subject of this paper is whether the aforementioned rule and the rules regarding the alienation of some contracts in Iranian law and jurisprudence is known as a peremptory rule, or it is one of the alienative rules of choice and therefore, a mutual consent and agreement against them is also possible. Of course, considering the fact that agreement on changing the time of alienation includes the two states of advancing and postponing the alienation time and it is not possible to study both of these hypotheses in this paper, we only examine the two parties' agreement on alienation before signing the contract. For this purpose, we first need to examine whether the two parties' will be principally capable of totally changing the effects of the contract, including the time of alienation (speech 1), and then examine the effect of the two parties' agreement on the subject of this paper, which is advancing the time of alienation (speech 2).

\section{Speech 1: The Effect of the Two Parties' Agreement in Changing the Contract's Consequences}

This session is mainly about studying the two parties' willpower to change the contract's consequences. The purpose is to see whether the two parties are able to separate the time of alienation from the time of signing the contract. To find the answer, a study of the two parties' willpower regarding general rules in contracts is required. We know that signing the contract, and the contract's consequences are two separate issues and the parties' will be usually dominant in signing the contract. For instance, acceptance should correspond with requirements, and through the requirements, the parties can specify conditions for acceptance; however, what is required, and the correspondence between the requirement and acceptance etc. are rules that depend on the condition of the contract's accuracy, and therefore the parties have no authority for changing them. In this regard, one of the discussions worth paying attention is suspending the contract's consequences, and its validity or invalidity. Iranian civil law does not give an explicit answer to this question. The Shia jurisprudence, which is one of the basic inspirations for Iranian legal system, has dispersed opinions as well. In general, there are two views regarding the two parties' authority: Some consider the contract's consequences to be lawful, and also believe separating the cause from the caused to be logically impossible. On the other hand, rejecting the aforementioned reasons, another group of Jurisprudents and lawyers respect the parties' will in changing the contracts' consequences. The following sessions explain each of these two views: 


\section{A. The View of Negating the Parties' Authority}

This view questions the parties' authority in determining the contract's consequences in two aspects: One being the lawful nature of the contract, and the other, believing the separation of the cause from the caused to be illogical. Each of these aspects is described as follows:

1. The Lawfulness of the Contract's Consequences

Some believe that the contract's consequences have lawful nature. In this view, the contract's consequences are not caused from the parties' will, but they are lawfully regulated.

The role of parties' will be to merely create a seeming cause called a contract to have its specific consequences according to the rule of the law and lawyer. Therefore, the role of will is limited to signing the contract: "Contracts are lawful causes and their consequences are by virtue of laws of scripture (Qare-Daaqi; 2002, p. 61). Accordingly, the parties' agreement cannot determine the time of alienation, and determining this time is exclusively based on law.

2. Impossibility of Separating the Cause from the Caused

As soon as the cause is created, the result and caused is also ascertained. Separating the cause from the caused is impossible (Najafi,1394). The contract of sale is the cause of possession, and as soon as the sale is done, the purchaser should become the owner, and the seller should be the price owner. The author of "Javaher al-Kalam" (Priceless Words) writes the following mandate contract: "One of the conditions is that, like other contracts, it will be incontrovertible... due to the conflicts of the condition of suspension with the necessity of connection between cause and the caused, which is one of the reasons of causality in acquired contracts" (Najafi,1394). By the connection between the cause and the caused, the author means the separation of cause from caused: i.e. the caused will be created as soon as the cause happens, and separating them is impossible.

\section{B. The View of Accepting the Parties' Authority}

The first view has been criticized, saying that firstly, the contracts' consequences have a willful nature, and secondly, there is no rational prohibition for accepting the separation of the contract's consequences (caused) from the contract itself (cause), according to the following reasons:

\section{The Willfulness of Legal Actions}

Some of the Jurisprudents and lawyers consider convention as the source of knowing the contracts' consequences and requirements, and limit the role of laws of scripture only to the conditions of their validity and obstacles. In this regard, in order to know the consequences of a contract as well as finding whether the rules regarding contracts are imperious, we should refer to conventions (Khouei, 1414). In other words, people have made contracts based on their needs, and they determine a contract's consequences based on the same needs. This process was done for specific contracts in the past, so that today people sign unspecified contracts with the same method and determine the consequences on their own. Therefore, here people create these contracts and determine their consequences based on their needs. However, there are cases where law has also a significant role in determining the contract's consequences: In contracts regarding job, family, insurance, social security, business companies etc. But it seems law does not have a significant role in determining the consequences in financial contracts. Basically, the role of law in the contract's consequences is a signature role as well as interpretive, supplementary and deterrent (Katoozian, 1380). When law introduces the contract's consequences, it actually shows the individuals' typical and common demand from a specific contract, and is sometimes in order to complete the contract. On the other hand, it does not accept contracts that will result in violating ethics, public order and peremptory norms.

The view of considering the contracts' consequences to be lawful actually reminds one of the view that contracts are social. In this view in law, the contracts are rules for administration of justice or avoiding injustice, and not just an explanation of the parties' agreement. Based on this interpretation about contracts, and due to the legislators' interference in making regulations regarding public order, ethics, and supporting the rights of the third parties, insuring commutative justice between the contract's parties has been restricted and the parties' 
agreement is still determinative. If we consider the contracts' requirements to be lawful, we have assumed the contract to be a legal event in a way. However, all legal systems can be divided into legal event and legal action (Katoozian, 1380). The consequences of usurpation are determined by law, but the same law leaves the consequences of contracts to the parties. It is as though the existence and nature of the contract is a creation of the parties' will. Therefore, the same creating will can omit or change the contract's non-essential consequences. Hence, we should say that basically, the law of scriptures or law does not determine the contract's requirements (Ansari, 1425); since the contract's requirement depends on the people's needs.

The role of law is just to verify and sign this means in order to reach the wanted results.

Therefore, what is important in the beginning is not that a specific contract necessarily requires a specific result, but it actually should make sure that it will result in what the parties intended.

\section{Accepting the Separation of Cause from Caused in Credential Affairs}

The impossibility to separate cause from caused as one of the reasons in the first view, has two arguments by itself: On one hand, according to general intellectual rules, it is impossible for the caused to violate the cause. As soon as a cause happens, the caused is instantly created.

On the other hand, the consequences of contracts will be reached as soon as they are required and accepted: signing the contract is the cause and its consequences are caused (QareDaaqi, 2002). In this regard, it is said that, firstly, there is a difference between the cause and the requirement: the final cause is created from the requirement and lack of obstacles (Jafari Langeroodi, 1382), and what is connected to the caused is the final cause. But the cause can be separated from its requirement. An example is pending contract, which has accepted validity in Iran, but its consequences are postponed until the time of receiving the pending object (Ghasemi, 1382). Secondly, assuming the definite causality is accepted for requiring and accepting the contract, we should say that law is the world of interests and validity, and the rule of natural cause and effect should not be used in contracts and rhythmic (Langeroodi, idem).

"The form of credit balance is no more than the world of credit; therefore, these are created upon credit and they do not need to be materially existent. Hence, credit is suddenly dependent to present time. So, the validator validates his house's ownership to someone else at present time. In another instance, the credit is a matter in the future, such as property credit for a person after a specific time, in a way that the testator's will gives credence to the legatee. Here the present's validity and its effect are related to the future" (Khouei, 1414).

In other words, the experts who agree on advancing alienation in sale believe that the idea of contrast is because the ownership is considered to be an external reality; while it is a concept made by mind and also a means for better representing the authority to exclusive exploitation of property. By agreeing upon advancing the alienation, we mean that the seller will not only give the customer the exclusive authority for the object of sale, but he also gives the results of privileges that he had considered in the intended advanced date. The convention's simple mind accepts this consent and doesn't consider it to be impossible. Article 258 in Iranian civil law also states: "In regard of financial interests which are under unauthorized transactions and also the interests gained from its alternative, authority or rejection will be effective from the day of signing the contract" and verifies the same view. Of course, some may say that the article 258 is about interests and does not speak of the object itself (Shahidi, 1380). Therefore, the legislator actually validates the authority in relation to the ownership of the object of transporter and the ownership of interests. Assuming this is true; the legislator still considers the previous benefits of the object of sale to be the purchaser's property, and the purchase money's previous benefits to be the seller's property. When authority can transfer the benefits from the past, which do not exist now, to the purchaser, then the theory of willpower in the past is verified. Therefore, we can expand what this article means by "in relation to interests" to object ownership and the benefits of the object of sale and the personal purchase price from the first day, and say that the legislator knows the ownership of interests to be credential. Using this article and the fact that 
legal natures are credential, we can accept the principle of freewill to create any legal nature at any time (Katoozian,1366).

\section{Speech 2: The Parties' Agreement on Advancing the Alienation time in Possessory contracts}

In the previous session, we discussed the credence of the parties' agreement regarding the changing of the contract's consequences in general, and after discussing the reasons of two groups of Jurisprudents and lawyers, we found out that accepting the two parties' authority in changing the contract's consequences seem logical. In this article, we examine whether the parties' agreements in advancing the time of alienation in possessory contracts corresponds to these contracts' specific characterization. In other words, we should see whether the condition of advancing the time of alienation contrasts with the requirements of creating it. I.e. is "time" matter of the nature of possessory contracts for alienation, or is it a matter of using them?

In this regard, some believe that instant alienation is part of the nature of possessory contracts such as selling, and therefore, not only agreeing upon them is invalid, but it also cancels the contract. While another group believe that the contract's requirement and the real intention of possessory contracts is transferring the ownership of the object of sale and the purchased price, and not necessarily transferring them in a specific time (Ansari, 1425).

As some masters have said in this regard, "we should not assume that instant alienation without any conditions about the object of sale and the purchase price is a requirement of the sale: The alienation is done, but only through the condition that the subject of the contract has the capability" (Katoozian, 1380).

According to what has been said, the requirement of the nature of contract of sale is only alienating the object to the certain alternative. If the object of sale is specified at the time of signing the contract, this alienation can be instantly being done (instant alienation) and it can also be done after signing the contract and at the time of determining the applicable object for the described object of sale (general sales). Therefore, when the object of sale is determined, there is no problem in alienation after the parties' intended conditions are reached. Article 469 in Iranian civil law also explicitly mentions this latter part and states: "the time of lease starts from the day determined between the two parties. If the beginning of the time is not mentioned in the lease contract, the time of signing the contract will be considered". This shows that the condition of target date in alienation will be valid if the alienation is postponed for a while.

Accordingly, many lawyers believe that the two parties can postpone the alienation for some time.

Of course, the truth is that the requirement of the contract of sale and other possessory contracts is not the urgency of alienation, but the transferring itself, with no regard to the time of signing the contract. At that time, since the cause of alienation, meaning the parties' will is there and this will has demanded the alienation at the same time, then the alienation will be done at this time. But there will be no obstacles if the same will demands the alienation to be done in another time and under better conditions.

On this basis, we should state that agreement upon advancing alienation from the time of signing the contract, for instance, in a way that the two parties sign the contract of sale today under the condition that the consequences, i.e. alienation are done beforehand, is valid in Iranian law.

Another question is whether it is necessary that the agreement is made as a consequential condition at the time of possessory contract and in the form of an obligation in the contract itself. Or will this agreement still be valid and effective if it is done independently apart from this contract or upon signing another contract? It seems like the parties' agreement should be reached conditionally at the time of signing the original contract, since this condition lacked a subject before signing the contract, and the alienation has been completely done after signing it and therefore, there is no consequence to it. Also, we should find how the effect of this condition would show in practice. When someone says that he will sell you his car and set the 
date of contract to two months ago, it means that he will give you the results of interests he has received for two months ago (Katoozian, 1384).

The ownership of the car has had consequences in the past two months: for instance, its interests belonged to the owner at that time, and if any harm has been done to someone through this property, the owner of that time has been taken responsible (article 333 of civil law); the property tax of those two months has been assigned as debt. In this case, the ownership of the interests of the object of sale, which have been established two months ago, in case they actually exist (e.g. fruit), will be transferred today; and if the usurper or tenant have lost it, their alternative has been established in the seller's property and the demand exists at the moment, which the seller will transfer to the purchaser. Moreover, the two parties have right of lien. Any danger can occur to the two parties, and transferring the danger depends on submission (article 387 of civil law). But a delay in paying the purchase price is effective from the day of signing the contract, and the compensation of debt delay will not depend on the past days. In other words, the obligatory effects will be established from the day of signing the contract, but the situational effects will be established from the day that the two parties have assigned.

\section{Conclusion}

Transfer the ownership is one of the most important issues in the contracts Law, which regarding the peculiar situation of possessory contracts in jurisprudence and therefore Iran's law (which states that the alienation starts from the time of signing the contract and not from the time of submission), has also been the source of other important issues such as exchange guarantee, loss of sales before the purchase etc. Therefore, examining the related issues and discussions can be one of the most common and useful discussions in practical and theoretical areas. This paper examined the effect of the two parties' will in advancing the time of alienation in possessory contracts. The studies show that instant alienation in possessory contracts is a requirement of the contract's assignment and not a requirement of its nature. In other words, whenever the contract is signed in this area by itself and without any condition, it is assumed that the parties' implied will is that the created cause (the so-called contract) will have its legal effect instantly and without any delay. Nut if the parties of the contract agree in a different way at the time of signing the contract, there is no prohibition to accepting the agreement and condition while signing the contract. Of course, as it was shown, there is more disagreement on the condition of advancing the alienation, and avoiding the creation of the caused (alienation) before the existence of cause (contract) or opposition of such a condition with the peremptory norms, including article 362 in contract of sales etc. has been said to be likely. But based on what has been said, the preferred view is the one which considers instant alienation to be a requirement of assigning the contract and validates an agreement against this. Accepting this view, regarding the fact that the rules of transactions are usually among alternative choice and not mandatory ones, and also considering the principle of freewill in contracts in order to supply the social needs in people's relationships, can help reducing the theoretical and practical problems in this subject. However, the silence of Iranian civil law in this regard, which some define as a silence in expression, has resulted in the continuation of disagreements in this area.

Therefore, we suggest a modification of rules and admitting to accept the agreement between parties in changing the time of alienation, to remove any doubts in this regard.

\section{REFERENCES}

1. Ansari, S. M. (1425). Almakaseb, Vol. $3 \& 6,1^{\text {st }}$ edition, Qom, World Congress for Sheikh Azam Ansari's Commemoration.

2. Emami, S. H. (1366). Civil Law, vol. 1 \& 3, $10^{\text {th }}$ edition, Tehran, Eslamieh Bookshop.

3. Katoozian, A. (1366). Will in Iranian Civil Law, $2^{\text {nd }}$ edition, Tehran, Central Lawyers Club.

4. Katoozian, A. (1380). Legal Actions, $11^{\text {th }}$ edition, Tehran, Joint publicatin co. 
5. Katoozian, A. (1384). General Rules of Contracts, 5 vols. $8^{\text {th }}$ edition, Tehran, Katoozian Law Foundation.

6. Khouei, A. (1414). Mesbah al-faghahe, vol. 33, Qom, Imam Khouei Revival Institute.

7. Langeroodi, J., Jafar, M. (1381). An Encyclopedia of Civil Law and Business, $1^{\text {st }}$ edition, Tehran, Ganje Danesh Publication.

8. Langeroodi, J., Jafar, M. (1382). Supreme Philosophy in the Science of Law, $1^{\text {st }}$ edition, Tehran, Ganje Danesh Publication.

9. Najafi, M. H. (1394). Javaher al-Kalam fi Sharaei al-Islam, vol. 28, Lebanon.

10. Shahidi, M. (1380), The Effects of Contracts and Commitments, vol. 3, $2^{\text {nd }}$ edition, Tehran, Majd Community of Science and Culture.

\section{Article history:}

- $\quad$ Received 25 August 2017

- Accepted 10 December 2017 